\title{
緑内障治療薬アセタゾラミドの体内動態と薬効の速度論的解析†
}

\author{
矢野育子 \\ 京都大学医学部附属病院薬剂部 $\dagger^{2}$
}

\section{Pharmacokinetics and Pharmacodynamics of Acetazolamide in Patients with Intraocular Pressure Elevation ${ }^{\dagger}$}

\author{
Ikuko Yano \\ Department of Pharmacy, Kyoto University Hospital $\dagger^{2}$
}

$\left[\begin{array}{l}\text { Received December 18, } 2001 \\ \text { Accepted January 8, } 2002\end{array}\right]$

\begin{abstract}
Although acetazolamide, a carbonic anhydrase inhibitor, has an effect of lowering the intraocular pressure, a number of side effects have been reported with its use. We therefore investigated the pharmacokinetics and pharmacodynamics of acetazolamide in patients with an intraocular pressure (IOP) elevation. The plasma acetazolamide concentration and IOP in 17 patients with a transient IOP elevation were simultaneously measured after the last acetazolamide administration, and the findings were analyzed by nonlinear mixed effect modeling using the NONMEM software program. The plasma concentration profile of acetazolamide was characterized by a one-compartment model with first-order absorption. The apparent oral clearance $(\mathrm{L} / \mathrm{hr})$ showed a correlation with the creatinine clearance $(\mathrm{CCR}, \mathrm{mL} / \mathrm{min})$, as estimated by the Cockcroft and Gault equation, as follows : $0.0468 \cdot \mathrm{CCR}$. The estimated apparent oral volume of the distribution, first-order absorption rate constant, and absorption lag time were $0.231 \mathrm{~L} / \mathrm{kg}, 0.821 \mathrm{hr}^{-1}$, and $0.497 \mathrm{hr}$, respectively. The intraocular pressure after oral acetazolamide administration was characterized by an $\mathrm{E}_{\max }$ model. The maximal effect in lowering the IOP ( $\left.\mathrm{E}_{\max }\right)$ was $7.2 \mathrm{mmHg}$, and the concentration corresponding to $50 \%$ of $\mathrm{E}_{\max }\left(\mathrm{EC}_{50}\right)$ was $1.64 \mu \mathrm{g} / \mathrm{mL}$. We next investigated the relationship between the acetazolamide concentration and its side effects in 23 glaucomatous patients who received repeated doses of oral acetazolamide for one week or more. The serum concentration of chloride ion was found to be higher than the normal range, and also showed a significant correlation with the acetazolamide concentration in the erythrocytes. The patients with an erythrocyte acetazolamide concentration of more than $20 \mu \mathrm{g} / \mathrm{mL}$ had higher incidents of the side effects. Based on these results, the recommended dosage of acetazolamide was calculated so that the minimum plasma concentration at steady-state exceeded $4 \mu \mathrm{g} /$ $\mathrm{mL}$. The dosage regimen desired in this study is expected to contribute to the safe and effective pharmacotherapeutic use of acetazolamide.
\end{abstract}

Keywords — acetazolamide, intraocular pressure, pharmacokinetics, pharmacodynamics, NONMEM

\section{はじめに}

わが国における臨床薬剤業務の歴史は，入院調剤技術 基本料が制度化された昭和63年に始まるといえる。その
後平成 4 年に第 2 次医療法改正が行われ，薬剤師が医 師，看護婦とともに医療の担い手として明記されたこと は薬剤師にとって大きな変革であった。平成 6 年には入 院調剂技術基本料は薬剤管理指導料と名称変更され，保

$\dagger^{1}$ 本論文は，平成13年度日本医療薬学会奨励賞の受賞業績を中心に記述したものである.

$\dagger^{2}$ 京都市左京区聖護院川原町54; 54, Kawahara-cho, Syogoin, Sakyo-ku, Kyoto-shi, 606-8507 Japan 
2

険点数は増加の一途をたどっている。平成 13 年 9 月 30 日 現在，全国4866施設で薬剂管理指導業務の届出が行われ ており,今や薬剤管理指導業務は病院薬剤師の中心的業 務といえる。

京都大学医学部附属病院薬剤部では, 従来より薬剂管 理指導業務を調剂, 医薬品情報, TDM, 製剂等, すべ ての薬剤業務を包括するものとしてとらえ発展させてき た．平成元年には，まず小児科において抗てんかん薬の TDM を行っている患者を対象に病棟業務を開始し，そ の後，第二内科，眼科，耳鼻科，第三内科と対象科を広 げ，平成11年より全診療科を対象としている。眼科では 糖尿病等内科的合併症の患者が多く, 薬学的管理を必要 とする場合も多いのではないかということで，比較的早 期の平成 6 年から病棟業務を開始した。著者らは眼科で の薬剂管理指導業務を始めてまもなく, 緑内障治療薬ア セタゾラミドの適正使用に問題のある症例を経験し，そ れを契機として翌年には眼科との共同研究を開始した。 本稿では, 眼科における症例および著者らが行った一過 性高眼圧患者におけるアセタゾラミドの体内動態（フ アーマコキネティックス) と薬効（ファーマコダイナ ミックス）の非線形混合効果モデル解析 ${ }^{1)}$, 緑内障患者 における副作用評価 ${ }^{2)}$ ，および腎機能別アセタゾラミド

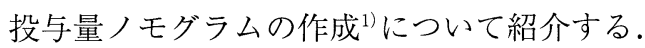

\section{症例}

まず，著者らがアセタゾラミドの体内動態と薬効の速 度論的解析を行うに至った症例について紹介する（Case $1)^{3)}$. 患者は49歳男性で, 増殖性糖尿病網膜症および 新生血管緑内障の治療のため眼科に入院中であった。糖 尿病，糖尿病性腎症，心不全，高血圧症の治療のため内 科から処方薬があったが, さらに眼科より, 眼圧上昇時 にアセタゾラミドとアスパラギン酸カリウムが追加処方 された.この患者に対する薬剤管理指導として，1つに

Case. 1. 糖尿病性腎症患者におけるアセタゾラミド の投与について

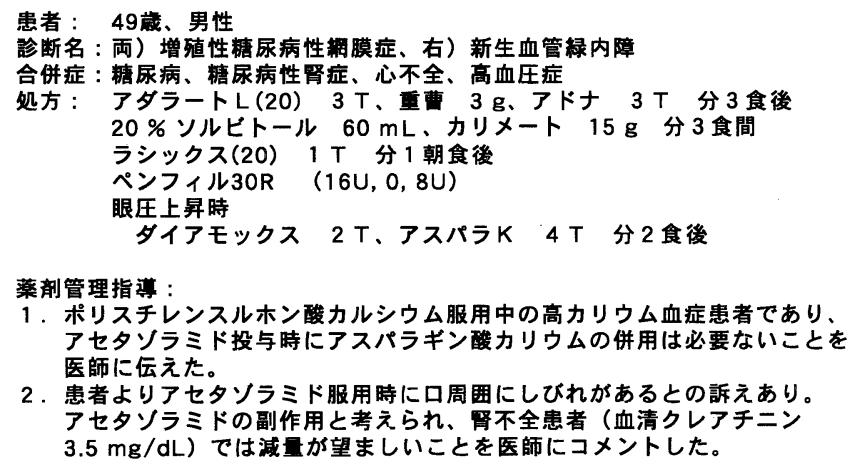

は，ポリスチレンスルホン酸カルシウム服用中の高カリ ウム血症患者であり，アセタゾラミド投与時にアスパラ ギン酸カリウムの併用は必要ないことを医師に伝えた。 さらに，服薬指導時に患者からアセタゾラミド服用時に 口周囲がしびれるとの訴えがあった。これはアセタゾラ ミドの副作用と考えられ, 患者が腎不全状態（血清クレ チニン值 $3.5 \mathrm{mg} / \mathrm{dL})$ にあり, アセタゾラミドが腎排泄 型の薬物であることを考慮すれば減量が望ましいことを 医師にコメントした。この症例のようにアセタゾラミド の副作用発現頻度は高いにも関わらず，アセタゾラミド の投与量は患者の年齢, 腎機能を考慮することなく, 眼 圧に応じて決定されていた。

\section{1. アセタゾラミドについて}

炭酸脱水酵素阻害薬であるアセタゾラミドは, 緑内障 治療薬として眼科で広く使用される。炭酸脱水酵素阻害 薬は毛様体上皮中に存在する炭酸脱水酵素の作用を阻害 することによって，房水の産生を減少させる ${ }^{4)}$.アセ夕 ゾラミドの副作用については, 血液障害等の重篤な副作 用の発現頻度は少ないものの，投与された患者の約50\% が，悪心・嘔吐，倦㤐感，しびれ等の副作用を訴えるこ とが知られている5).これら副作用の原因について詳細 は不明であるが，アシドーシスあるいは炭酸ガスの蓄積 と関連があることが示唆されている4).アセタゾラミド の過量投与は，全身性アシドーシスの増強によってさら に眼圧を低下させるため, 眼圧の低下のみによって治療 のモニタリングを行うことは十分ではないと考えられ る、したがって，アセタゾラミド血中濃度をモニターす ることが重要と考えられるが, 臨床的にはほとんど行わ れていないのが現状である，また，眼圧を十分下げるた めに必要なアセタゾラミド血漿中濃度については, 4 $5 \mu \mathrm{g} / \mathrm{mL}$ あるいは， $10 \mu \mathrm{g} / \mathrm{mL}, 15-20 \mu \mathrm{g} / \mathrm{mL}$ との相反 する報告があり，一致した見解は得られていない年-9).

一方，体内に投与されたアセタゾラミドのほとんど は, 未変化体のまま尿中に排泄されることから ${ }^{10)}$, 腎障 害の患者や高齢者においては投与量を減じる必要があ る $^{11-13)}$.しかしながら,アセタゾラミドは約50年前に開発 された薬物であるものの, 患者における腎機能と体内動 態パラメータとの関係についての情報は不足している.

そこで著者らは, 腎機能とアセタゾラミド体内動態パ ラメータの関係, 眼圧を下げるために必要とする血中濃 度，および副作用と血中濃度の関係について解析し, 腎 機能に基づくアセタゾラミド投与設計を行うことを目的 に研究を行うこととした。 
Table 1.アセタゾラミドの体内動態と薬効の解析に 用いた患者データの特徵

\begin{tabular}{ll}
\hline 患者数(女性) & $17(11)$ \\
年齢(歳) & $67.4 \pm 10.5$ \\
体重 $(\mathrm{kg})$ & $55.0 \pm 9.1$ \\
血清クレアチニン $(\mathrm{mg} / \mathrm{dL})$ & $1.56 \pm 0.66$ \\
クレアチニンクリアランス $(\mathrm{mL} / \mathrm{min})^{\mathrm{a}}$ & $36.7 \pm 13.7$ \\
単回投与 : $62.5 \mathrm{mg}$ & 1 \\
$125 \mathrm{mg}$ & 1 \\
$250 \mathrm{mg}$ & 8 \\
反復投与 : $250 \mathrm{mg}$ 分 2 & 1 \\
$500 \mathrm{mg}$ 分 2 & 5 \\
$1000 \mathrm{mg}$ 分 2 & 1 \\
血中濃度測定総数 & 69 \\
眼圧測定総数 & 79 \\
\hline
\end{tabular}

Mean \pm S.D. aCockcroft と Gaultの式による

\section{2. 高眼圧患者におけるアセタゾラミド体内動態の速度 論的解析 ${ }^{1}$}

対象は本院眼科入院中で, 術後の一過性高眼圧治療の ためアセタゾラミドが投与された患者17名である．Table 1 には，解析に用いた患者データの特徵を示す．年 齢は平均67.4歳で，49～85歳の患者が含まれていた。体 重の平均は $55.0 \mathrm{~kg}$, 腎機能の指標である血清クレアチニ ン值の平均は $1.56 \mathrm{mg} / \mathrm{dL}$ (Jaffé 法) であった。また, Cockcroft と Gault の式 ${ }^{14)}$ から求めたクレアチニンクリ アランスは $15.4 \sim 58.3 \mathrm{~mL} / \mathrm{min}$ で, 平均 $36.7 \mathrm{~mL} / \mathrm{min}$ で あった.アセタゾラミドの 1 回投与量は，62.5 500mg で, 単回投与後の患者が 10 名, 反復投与後の患者が 7 名 含まれていた．また，患者は種々の内服薬を服用してい たが, 緑内障治療のための点眼薬は使用していなかった。

患者は, 眼圧に応じて主治医が決定した投与量のアセ タゾラミドを朝 9 時に服用した。薬効の指標である眼圧 の測定は，基本的にはアセタゾラミド投与前と投与後 $1,3,5,9$ 時間に Goldmann 圧平眼圧計により行い, 同時に採血を行い, アセタゾラミド血中濃度を HPLC 法 ${ }^{15)} に よ り$ 測定した。17名から得られた血漿中濃度69 点ならびに眼圧79点を用いて, 体内動態と薬効の速度論 的解析を非線形混合効果モデルプログラム NON$\mathrm{MEM}^{16,17)}$ を用いて行った。

Fig. 1 はアセタゾラミド投与後の時間に対して血漿中 濃度をプロットしたものである。同一患者間のデータは 点線で結んでいる。 また，白丸は反復投与後の血漿中濃 度を, 黒丸は単回投与後の血漿中濃度を示す.アセタゾ ラミド血漿中濃度の個人差は大きく, 血漿中濃度のピー ク值は $2 \sim 32 \mu \mathrm{g} / \mathrm{mL}$ であった。

薬物動態モデルは 1 次吸収 1 コンパートメントモデル を用い, 誤差モデルとしては, 個体間・個体内変動とも 対数正規分布を仮定した。初期モデルとしては，見かけ の経ロクリアランス $(\mathrm{CL})$ は体重に比例するとしたが,

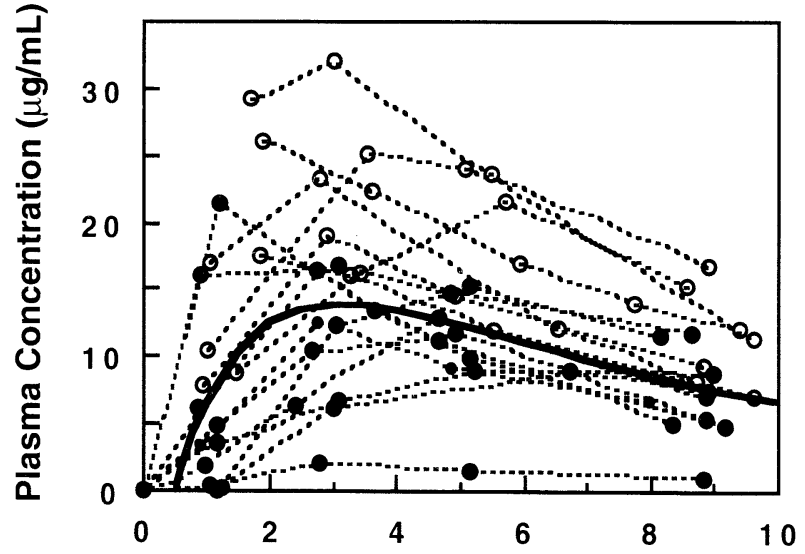

Time after the Last Administration (hr)

Fig. 1. 一過性高眼圧患者17名に扮ける経口投与後 のアセタゾラミド血漿中濃度推移

黒丸, 白丸は, それぞれ単回投与, 反復投 与後の血槳中濃度を示し, 同一患者の濃度 は点線で結んである。実線は, 体重 $50 \mathrm{~kg}$, クレアチニンクリアランス $36.7 \mathrm{~mL} / \mathrm{min}$ の平 均的な患者に $250 \mathrm{mg}$ 単回投与した場合の血 漿中濃度を, Table 2 に示す体内動態パラ メータの平均值に基づきシミュレーション したものである.

アセタゾラミドは主として腎臟から排泄されるため, ク リアランスとクレアチニンクリアランス (CCR) の関係 についてモデル化した $\left(\mathrm{CL}=\theta \mathrm{CCR}^{*} \mathrm{CCR}\right)$. 解析の結果, クリアランスがクレアチニンクリアランスと比例すると したモデルでは，モデルフィットの指標である OBJ の 值は初期モデルに比べ有意に小さく，またクリアランス の個体間変動は初期モデルの61.3\%から29.0\%に減少し たことから, クリアランスの個体差として腎機能の寄与 が大きいことが示された (Table 2)，すなわち，見か けの経ロクリアランスとクレアチニンクリアランスの関 係は次式で表された：CL $(\mathrm{L} / \mathrm{hr})=0.0468^{*} \mathrm{CCR}(\mathrm{mL} /$ $\mathrm{min})$. また, 分布容積の平均は $0.231 \mathrm{~L} / \mathrm{kg}$, その個体間 変動は $16.8 \%$ であり, 1 次吸収速度定数は $0.821 \mathrm{hr}^{-1}$, 吸収のラグタイムは $0.497 \mathrm{hr}$ ，それらの個体間変動はそ れぞれ $89.1 \%$ と 101\%，残差変動は血中濃度の7.9\%で あった。

Fig. 1 における実線は, 最終の体内動態パラメー夕を 用いて，クレアチニンクリアランスが $36.7 \mathrm{~mL} / \mathrm{min}$ で体 重が55kg の平均的な患者に250mg のアセタゾラミドを 投与した場合の血中濃度推移を示したものである.

\section{3. 高眼圧患者におけるアセタゾラミド薬効の速度論的 解析 ${ }^{1}$}

続いて, 血中濃度と同時に得られた眼圧を用いてアセ 
Table 2. 一過性高眼圧患者におけるアセタゾラミド 体内動態パラメータの最終推定值とその信 頼区間

\begin{tabular}{ccc}
\hline パラメータ & 推定値 & $95 \%$ 信頼区間 \\
\hline$\theta_{C C R}{ }^{\mathrm{a}}$ & 0.0468 & $0.0401,0.0535$ \\
$\mathrm{~V}(\mathrm{~L} / \mathrm{kg})$ & 0.231 & $0.190,0.272$ \\
$\mathrm{k}_{\mathrm{a}}\left(\mathrm{hr}^{-1}\right)$ & 0.821 & $0.626,1.02$ \\
$\mathrm{t}_{\mathrm{lag}}(\mathrm{hr})$ & 0.497 & $0.181,0.813$ \\
$\mathrm{CL}$ の個体間変動 $(\%)$ & 29.0 & $11.9,39.2$ \\
$\mathrm{~V}$ の個体間変動 $(\%)$ & 16.8 &,- 26.2 \\
$\mathrm{k}_{\mathrm{a}}$ の個体間変動 $(\%)$ & 89.1 & $62.9,109$ \\
$\mathrm{t}_{\text {lag }}$ の個体間変動 $(\%)$ & 101 &,- 187 \\
残差変動 $(\%)$ & 7.9 &,- 11.5 \\
\hline
\end{tabular}

個体間変動と残差変動は対数正規分布を仮定した，一： 推定不可能

${ }^{\mathrm{a}} \mathrm{CL}(\mathrm{L} / \mathrm{hr})=\theta_{\mathrm{CCR}} * \mathrm{CCR} ; \mathrm{CCR}$, クレアチニンクリアラン

ス $(\mathrm{mL} / \mathrm{min})$

$\mathrm{V}$ : 見かけの分布容積, $\mathrm{Ka}: 1$ 次吸収速度定数,

$\mathrm{t}_{\mathrm{lag}}$ ：吸収のラグタイム, CL：見かけの全身クリアラン ス

タゾラミドのファーマコダイナミックス解析を行った。

一般には血漿中の非結合型薬物濃度が薬効と相関すると 考えられるため, 本研究では血漿中総濃度と同時に限外 ろ過法によって得られた非結合型濃度も測定した。その 結果，アセタゾラミドの血漿中総濃度と非結合型濃度は 線形性を示した（非結合型濃度 $=0.035$ 総濃度, $\mathrm{r}^{2}=$ $0.776, \mathrm{P}<0.005)$ 。また，血漿中総濃度を用いた場合 の薬効解析のモデルフィットは非結合型濃度を用いた場 合と同程度であったため, 臨床上取り扱いやすい血漿中 総濃度に基づく薬効パラメー夕を求めることにした。

Fig. 2 は，17名の患者における眼圧をアセタゾラミド血 漿中濃度に対してプロットしたものである。薬効には大 きな個体差が存在するが，同一患者内では多くの場合， 血漿中濃度の上昇とともに眼圧は下降した. また，一定 の血漿中濃度以上で眼圧はプラトーに達していると考え られた．Fig. 3 は，5人の典型的な患者におけるアセ夕 ゾラミド血漿中濃度と眼圧の関係を経時的にプロットし たものである.ID10やID14の患者では反時計回りのヒ ステレシスが認められたが，その他15名の患者では血漿 中濃度と薬効の間に時間的遅れは観察されなかった。し たがって，アセタゾラミドの血漿中濃度と作用部位での 濃度は速やかに平衡に達すると仮定し, 薬効モデルとし て $\mathrm{E}_{\max }$ モデルを用いて解析した。すなわち血漿中濃度 Cp における眼圧 IOP は, 薬物が存在しない時のベース ラインの眼圧 $\mathrm{IOP}_{0}$, 最大効果 $\mathrm{E}_{\max }, \mathrm{E}_{\max }$ の $50 \%$ の薬効を もたらす濃度 $\mathrm{EC}_{50}$ の 3 つの平均パラメー夕を用いて,

(1)式で表されると仮定した.

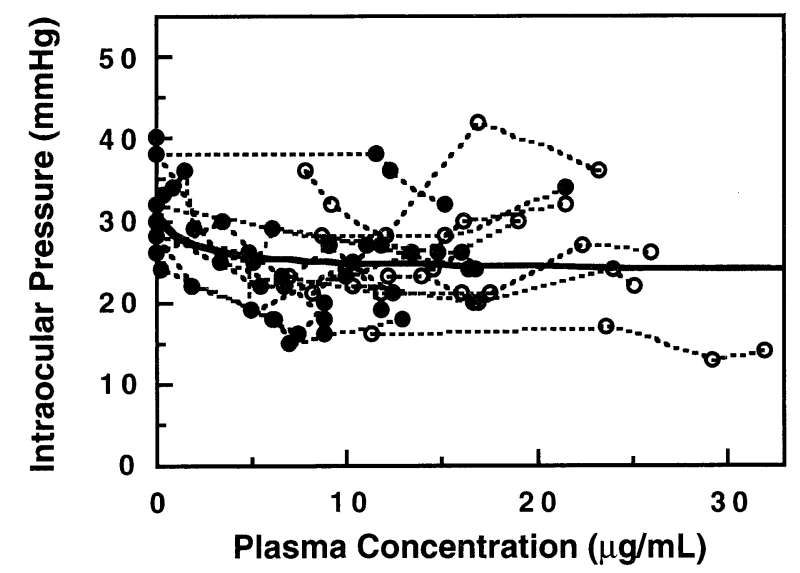

Fig. 2.一過性高眼圧患者17名における眼圧とアセ タゾラミド血漿中濃度との関係

黒丸，白丸は，それぞれ単回投与，反復投 与後の血漿中濃度を示し, 同一患者の濃度 は点線で結んである。

実線はTable 3 に示す薬効パラメータの平 均值に基づきシミュレーションしたもので ある。

$$
\mathrm{IOP}=\mathrm{IOP}_{0}-\mathrm{E}_{\max } \times \mathrm{Cp} /\left(\mathrm{EC}_{50}+\mathrm{Cp}\right)
$$

また，誤差モデルは個体間変動・残差変動ともに正規 分布を仮定した。

Table 3 は最終的に得られた薬効パラメー夕の推定值 とその信頼区間を示す． IOP 0 は $30.9 \mathrm{mmHg}, \mathrm{E}_{\max }$ は7.2 $\mathrm{mmHg}, \mathrm{EC}_{50}$ は $1.64 \mu \mathrm{g} / \mathrm{mL}, \mathrm{IOP}_{0}$ の個体間変動は S.D. として $4.6 \mathrm{mmHg}$ であり, 残差変動は S.D. として3.8 $\mathrm{mmHg}$ であった。なお， $\mathrm{E}_{\max }$ や $\mathrm{EC}_{50}$ の個体間変動は 0 と 比べて有意ではなかったため, これら個体間変動は最終 モデルには含まれていない。また， $\mathrm{EC}_{50}$ 值を無限大 $\left(10^{4}\right)$ あるいは，ほとんど $0\left(10^{-4}\right)$ に固定したところ， いずれの場合にも OBJの值は有意に増大したことか ら， $\mathrm{E}_{\max }$ モデルの妥当性を確認した。

Fig. 2 における実線は, 最終的に得られた薬効パラ メータに基づくアセタゾラミド血漿中濃度と眼圧の関係 を示す。すなわち, $\mathrm{E}_{\max }$ の70\%の薬効がアセタゾラミド 血漿中濃度 $4 \mu \mathrm{g} / \mathrm{mL}$ で得られ, それ以上の血漿中濃度で は薬効はほぼプラトーに達することが明らかとなった。

十分量の炭酸脱水酵素阻害薬は房水の産生を約 $40 \%$ 減 少させるが, 残り約 $60 \%$ の房水産生は炭酸脱水酵素に起 因しないことが知られている4). 本研究で得られた $\mathrm{E}_{\max }$ の值 $(7.2 \mathrm{mmHg})$ は $\mathrm{IOP}_{0}$ の平均值 $(30.9 \mathrm{mmHg})$ の $23 \%$ に相当するが，このようにアセタゾラミドの薬効が小さ く評価されたのは, 対象とした患者母集団の特徵の一つ と考えられる. 本研究で対象とした患者は 1 人を除いて は眼内手術後の患者であり, 術後には化学伝達物質の遊 


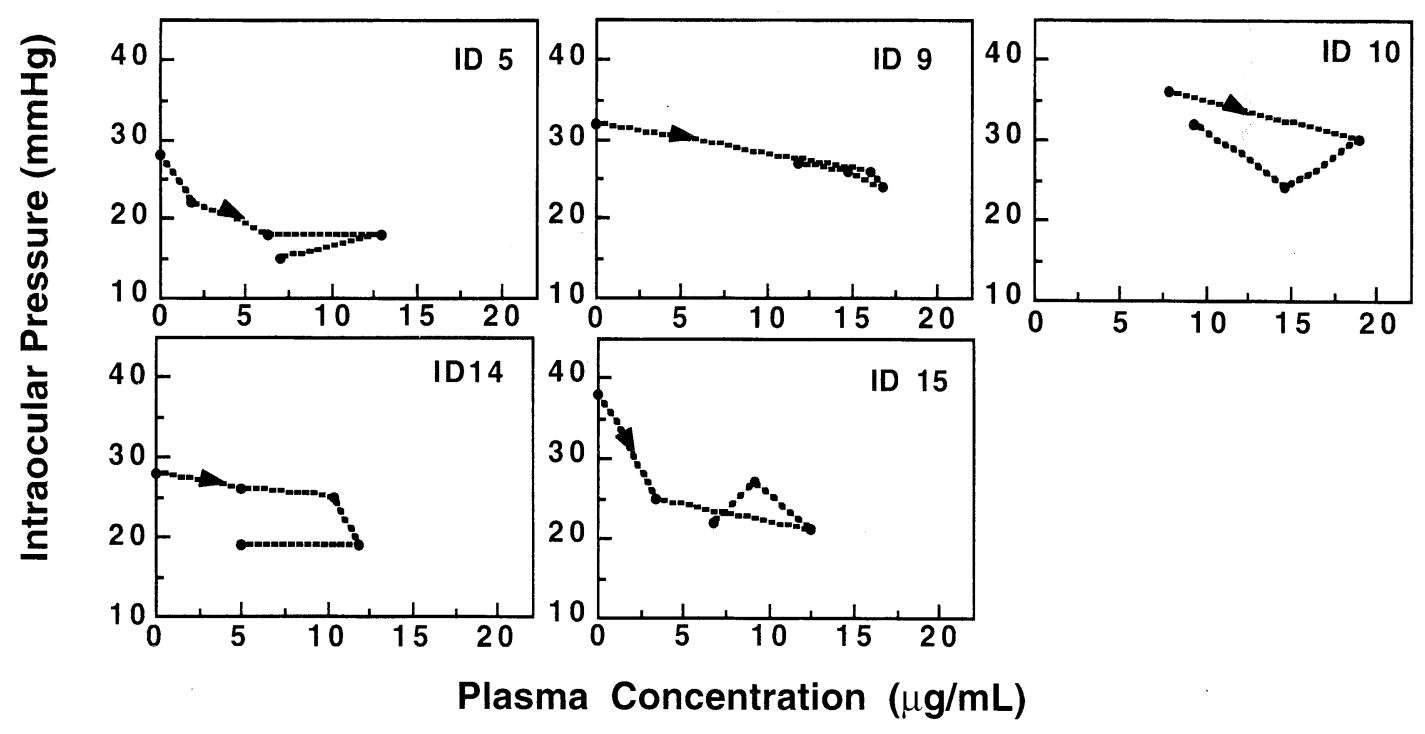

Fig. 3. 5 名の典型的な患者におけるアセタゾラミド経口投与後の血 漿中濃度と眼圧との関係 個々の点は経時的に結んでいる。

Table 3. 一過性高眼圧患者におけるアセタゾラミド 薬効パラメータの最終推定值とその信頼区 間

\begin{tabular}{ccc}
\hline パラメータ & 推定值 & $95 \%$ 信頼区間 \\
\hline $10 P_{0}(\mathrm{mmHg})$ & 30.9 & $28.7,33.1$ \\
$\mathrm{E}_{\max }(\mathrm{mmHg})$ & 7.2 & $4.2,10.2$ \\
$\mathrm{EC}_{50}(\mu \mathrm{g} / \mathrm{mL})$ & 1.64 & $-1.16,4.44$ \\
$\mathrm{IOP}_{0}$ の個体間変動 $(\mathrm{mmHg})$ & 4.6 & $2.8,5.9$ \\
残差变動 $(\mathrm{mmHg})$ & 3.8 & $2.5,4.8$ \\
\hline
\end{tabular}

個体間変動と残差変動は正規分布を仮定した $\mathrm{IOP}_{0}$ : ベースラインの $\mathrm{IOP}, \mathrm{E}_{\max }$ : 最大効果, $\mathrm{EC}_{50}$ ： $50 \% \mathrm{E}_{\text {max }}$ に対応する濃度

離や二次性隅角閉塞メカニズム等によって，アセタゾラ ミドによる眼圧低下作用は小さくなっていると考えられ る。また，眼圧の残差変動（個体内変動）は慢性の緑内 障患者の場合には本研究で得られた值よりもさらに小さ くなると推察される。

\section{4. アセタゾラミド血中濃度と副作用の関係 ${ }^{2)}$}

アセタゾラミド薬効の速度論的解析の結果，不必要な アセタゾラミドの増量は薬効の増強にはつながらないこ とが明らかとなったが，さらに血中濃度の上昇は副作用 の発現につながるか否か検討を行った．対象は本院眼科 通院あるいは入院中で, 緑内障治療のためアセタゾラミ ドを 1 週間以上継続服用している患者である。採血は最 終投与約 5 時間後に 1 回行った。アセタゾラミドは赤血 球に良く移行し, 副作用の発現が赤血球内濃度に関連す
Table 4. アセタゾラミド長期服用緑内障患者に おける投与量ならびに臨床検査值

\begin{tabular}{|c|c|c|}
\hline \multicolumn{2}{|l|}{$\begin{array}{l}\text { 患者数 (女性) } \\
\text { 年齢 (歳) }\end{array}$} & $\begin{array}{l}23(5) \\
54.8 \pm 22.8\end{array}$ \\
\hline \multicolumn{2}{|l|}{ 体重 (kg) } & $57.5 \pm 12.2$ \\
\hline \multicolumn{2}{|l|}{ 眼圧 $(\mathrm{mmHg})$} & $24.7 \pm 11.9$ \\
\hline \multirow[t]{4}{*}{ アセタゾラミド投与量 } & 250 (mg/day) & 7 \\
\hline & 500 & 14 \\
\hline & 750 & 1 \\
\hline & 1000 & 1 \\
\hline \multicolumn{2}{|c|}{ 血清クレアチニン $(\mathrm{mg} / \mathrm{dL})$} & $0.89 \pm 0.31$ \\
\hline \multicolumn{2}{|c|}{ 血清ナトリウム $(\mathrm{mEq} / \mathrm{L})$} & $142 \pm 4$ \\
\hline \multicolumn{2}{|l|}{ 血清カリウム $(\mathrm{mEq} / \mathrm{L})$} & $4.1 \pm 0.4$ \\
\hline \multicolumn{2}{|l|}{ 血清クロル (mEq/L) } & $110 \pm 3$ \\
\hline \multicolumn{2}{|l|}{ 副作用発現患者 } & 13 \\
\hline
\end{tabular}

るとの報告もあるため ${ }^{13)}$ ，本研究では血槳濃度と同時 に全血濃度もHPLC 法により測定した。副作用のモ二 ターは生化学検査値ならびに患者問診により行った.

Table 4 に, 副作用の解析に用いた患者デー夕の特徴 を示す．患者数は23名で，年齢の平均は54.8歳で13歳か ら80歳の患者が含まれていた。体重の平均は $57.5 \mathrm{~kg}$, 眼 圧の平均は $24.7 \mathrm{mmHg}$ であった。アセタゾラミド 1 日 投与量の多くは250 mg か500 mg であるが, $750 \mathrm{mg}$ や $1000 \mathrm{mg}$ の患者も含まれていた．血清クレアチニンの平 均は $0.89 \mathrm{mg} / \mathrm{dL}$ でほとんどの患者の腎機能は良好で あった．血清ナトリウム值や血清カリウム值に異常は認 められないものの, 血清クロル值の平均は $110 \mathrm{mEq} / \mathrm{L}$ と 正常值よりも高かった．また，23名中13名の患者は頻 尿，口渇，しびれ，悪心・嘔吐，全身倦点感等の副作用 を訴えた。 
Fig. 4 はアセタゾラミド血漿中濃度と赤血球内濃度と の関係を示したものである. 血漿濃度よりも赤血球内濃 度は高く，その関係は非線形性を示した。また，多くの 患者の血漿中濃度は $20 \mu \mathrm{g} / \mathrm{mL}$ 以下であるものの, $40 \mu \mathrm{g} /$ $\mathrm{mL}$ を超える患者も存在した。

Fig. 5 に, 血清クロル值とアセタゾラミド血漿中濃度 あるいは赤血球内濃度との関係について示す。血清ク口 ル值の正常值は99 106mEq/L であることから，23名中 19名のクロル值は正常值を超えていた. 血清クロル值の 上昇は血清重炭酸イオンの減少を反映するため, 代謝性 アシドーシスが起こっていることを示唆するものと考え る. また, 赤血球内濃度と血清クロル值は有意な正の相

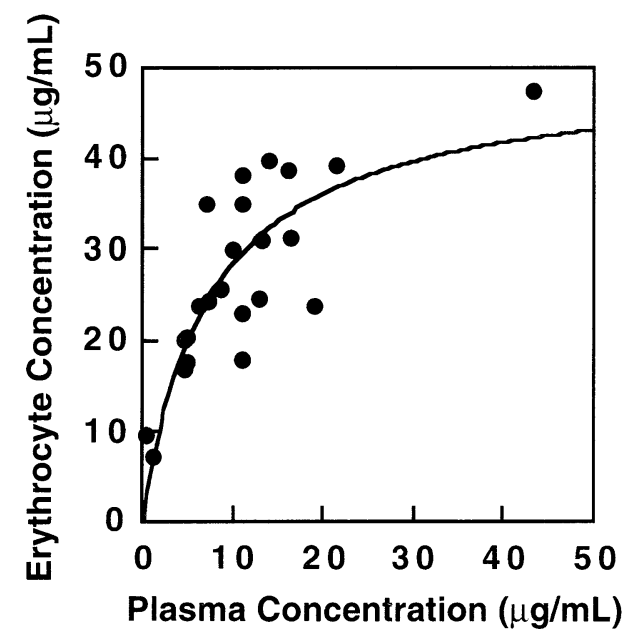

Fig. 4. 緑内障患者23名におけるアセタゾラミド赤 血球内濃度と血漿中濃度との関係 実線は非線形最小二乗法によるフィッティ ングカーブを示す (赤血球内濃度 $=49.7^{*}$ 血 漿中濃度/(7.54+血漿中濃度) )。
関を示すものの，血漿中濃度との間に相関は認められな かった。さらに, 副作用発現と赤血球内濃度との関係に ついて検討したところ, 副作用発現は赤血球内濃度が高 くなるにつれて増加する傾向が認められ, $20 \mu \mathrm{g} / \mathrm{mL}$ で 区切った場合, $20 \mu \mathrm{g} / \mathrm{mL}$ 未満では副作用の発現頻度は $16.7 \%$ あるるのに対し， $20 \mu \mathrm{g} / \mathrm{mL}$ 以上では $70.6 \%$ と有 意に高かった (Fig. 6). 一方, 血漿中濃度と副作用発 現頻度の間には有意な相関関係は認められなかった。

著者らの報告と同様に Heller らも, 長期アセタゾラミ ド服用中の高齢者の $55 \%$ に電解質異常と代謝性アシドー シスが起こっていることを報告している18). メカニズム については明らかではないものの, アセタゾラミドの赤 血球内濃度とそれに続く電解質異常が副作用発現に関連 する重要な因子と考えられる。アセタゾラミドを 2 週間 服用していた患者で投与を中止すると，アセタゾラミド の血漿中濃度は定量限界以下まで速やかに減少するもの の, 赤血球内濃度は120時間後まで検出可能であること が報告されている ${ }^{19)}$. したがって，アセタゾラミドの血 漿中濃度よりも赤血球内濃度の方が慢性投与時の患者に おける体内アセタゾラミド蓄積量を反映していると考え られる.さらに, 赤血球内には親和性の異なる 2 種の炭 酸脱水酵素アイソザイムが存在するが，アセタゾラミド はいずれのアイソザイムも阻害することが知られてい る20). したがって，アセタゾラミドの赤血球内濃度はア セタゾラミドによる炭酸脱水酵素阻害活性の強さを反映 し，副作用と関連することが推察される。

\section{5. 腎機能に基づくアセタゾラミドの投与設計 ${ }^{1)}$}

一過性高眼圧患者を対象としたアセタゾラミド体内動 態解析の結果, アセタゾラミドの全身クリアランスは患

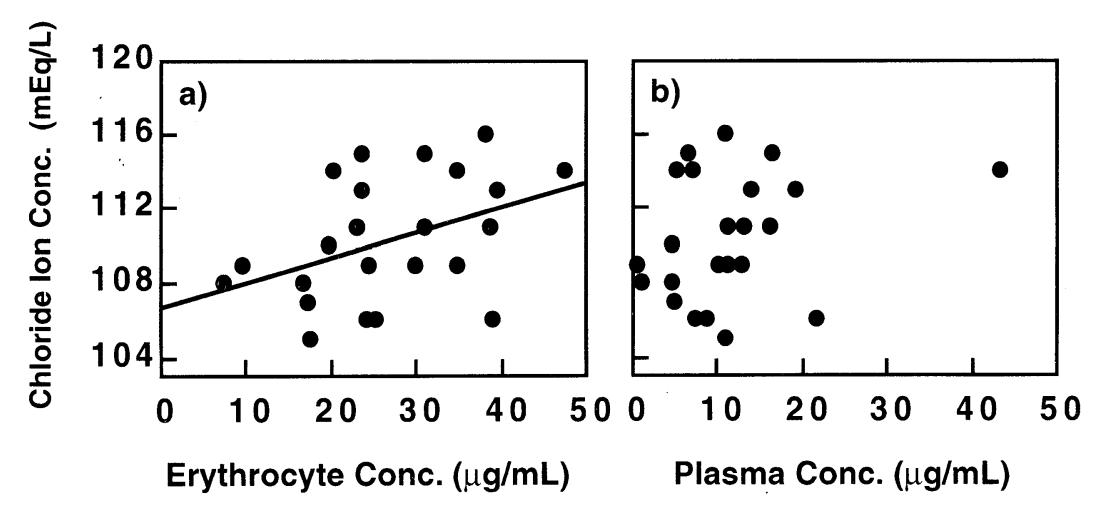

Fig. 5. 緑内障患者23名における血清クロル值とアセタゾラミド濃度との 関係

a）血清クロル值と赤血球内濃度の関係. 血清クロル值は赤血球内 濃度と有意な正の相関を示す $\left(\mathrm{r}^{2}=0.174, \mathrm{p}<0.05\right)$.

b）血清クロル值と血漿中濃度の関係. 血清クロル值は血漿中濃度 と有意な相関を示さない. 

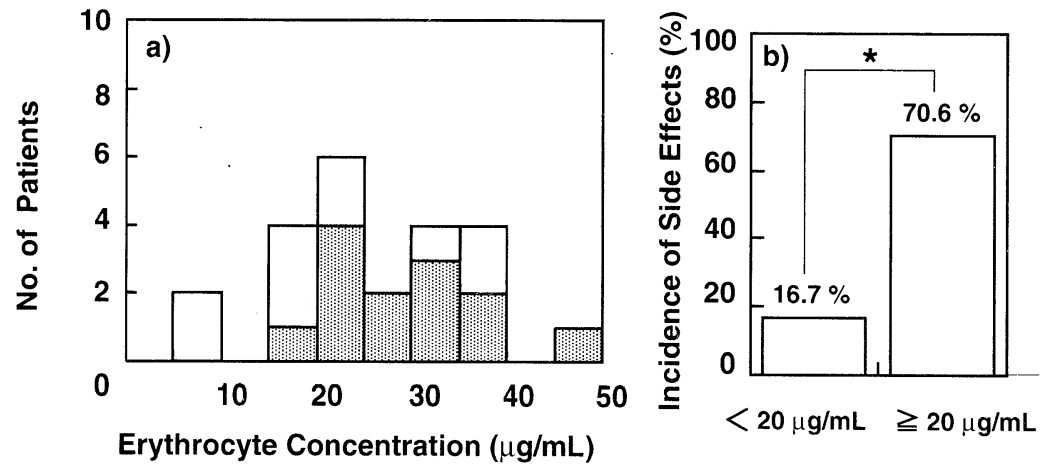

Fig. 6. 緑内障患者23名における副作用発現と赤血球内濃度との関係 a）白カラムは副作用を認めなかった患者を，点付きカラムは副 作用を認めた患者を示す． b ) 赤血球内濃度 $20 \mu \mathrm{g} / \mathrm{mL}$ で区切っ た場合, $20 \mu \mathrm{g} / \mathrm{mL}$ 以上の患者で副作用の発現頻度は有意に高 かった $(\mathrm{p}<0.05)$.

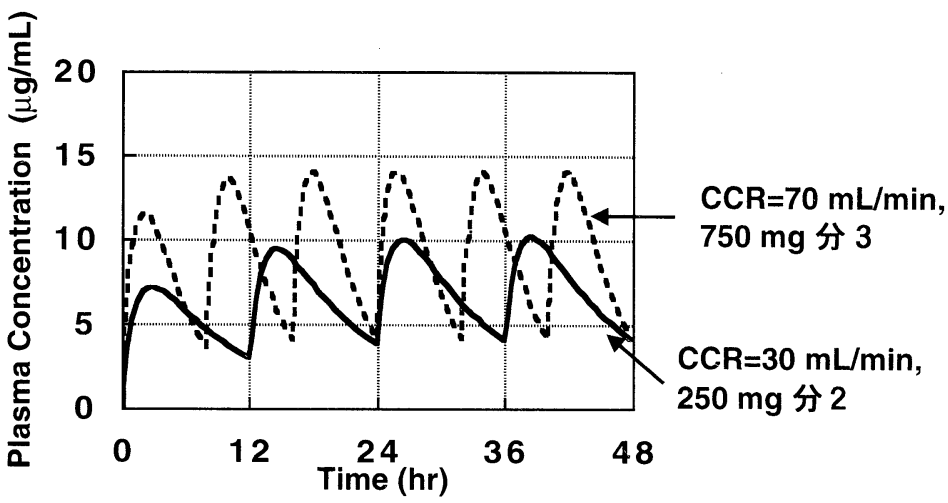

\begin{tabular}{|cc|}
\hline クレアチニンクリアランス(CCR) & 投与量 \\
\hline $70 \mathrm{~mL} / \mathrm{min}$ & $750 \mathrm{mg}$ 分 3 \\
50 & $375 \mathrm{mg}$ 分 3 \\
30 & $250 \mathrm{mg}$ 分 2 \\
10 & $125 \mathrm{mg}$ 分 1 \\
\hline
\end{tabular}

Fig. 7. アセタゾラミド血漿中濃度のシミュレー ションと腎機能に応じた投与量ノモグラム

者の腎機能と相関していることから，腎機能に応じた投 与量調節の妥当性が示された。 またアセタゾラミド薬効 解析の結果, 眼圧低下は血漿中濃度 $4 \mu \mathrm{g} / \mathrm{mL}$ 以上でほ ほプラトーに達することから, この濃度を有効血漿中濃 度の下限と考えた。さらに，アセタゾラミド長期服用中 の患者を対象とした検討の結果，アセタゾラミドの赤血 球内濃度と副作用には関連があることから, 不必要な増 量は薬効の増強とならないばかりか副作用発現につなが ることが明らかとなった。そこで体内動態の平均パラ メー夕值に基づき, 定常状態の最低血中濃度を $4 \mu \mathrm{g} /$ $\mathrm{mL}$ 以上とするような，腎機能に応じた投与量ノモグラ ムを作成した (Fig. 7$)$.このノモグラムの作成にあたっ ては市販製片がアセタゾラミド $250 \mathrm{mg}$ を含有している
ことを考慮した。すなわち，クレアチニンクリアランス が $70 \mathrm{~mL} / \mathrm{min}$ の患者では 1 日 $750 \mathrm{mg}$ 分 3 の投与が最適 であるが，クレアチニンクリアランスが $30 \mathrm{~mL} / \mathrm{min}$ に低 下した患者では $250 \mathrm{mg}$ 分 2 で同程度の効果が期待でき ると考えられる。

\section{6. 医療薬学と薬剤師}

以上，眼科に扔ける薬剂管理指導業務を通して得られ た問題点を契機に，医師との共同研究を行い，その成果 を臨床にフィードバックした例について示した。本研究 で得られた投与量ノモグラムは「腎機能別薬椷使用マ ニュアル」21)に記載されており，また新しく本院眼科に 入局した研修医に対しては，担当薬剤師によってこのノ 
8

モグラムが提供され，アセタゾラミドの適正使用に貢献

している。

医療薬学は薬剤師を支える学問であるが，医療薬学に も基礎と臨床があると考える。臨床，すなわち薬剤業務 によって見つけられた問題点やニーズは, 基礎にフィー ドバックされ，そして問題点あるいはニーズは基礎的に 解明され，再びその成果は臨床に還元される。こうした 基礎と臨床との相互のフィードバックが, 医療薬学・薬 剂師のいずれの発展にも不可欠ではないかと考える。今 回示したアセタゾラミドの研究は，こうした研究展開の 1 例ととらえている.

最近の医療を取り巻く環境の変化は著しく, 医薬品適 正使用, リスクマネージメント, 臨床試験, 医療経済 等，医薬品が関わるすべてに対して薬剤師として関与す ることが社会から求められている。したがって, 薬剤師 は科学的裏付け・学問的基盤を伴い薬剂業務を遂行する 必要があり, そのためには医療薬学のますますの発展と 基礎薬学・医療薬学の横断的連携が不可欠であると考え る.

謝辞 本研究は京都大学医学部附属病院薬片部と同・医学 研究科視覚病態学講座との共同で行われたものであり, 御指 導, 御鞭撻を賜りました乾 賢一教授, 本田孔士教授に深謝 いたします。さらに, 本研究に御協力いただいた共同研究者 の方々に厚く御礼申し上げます。

\section{引用文献}

1) I.Yano, A.Takayama, M.Takano, M.Inatani, H.Tanihara, Y.Ogura, Y. Honda, K. Inui, Pharmacokinetics and pharmacodynamics of acetazolamide in patients with transient intraocular pressure elevation, Eur. J. Clin. Pharmacol., 54, 63-68(1998).

2) M. Inatani, I.Yano, H.Tanihara, Y.Ogura, Y.Honda, K.Inui, Relationship between acetazolamide blood concentration and its side effects in glaucomatous patients, J. Ocular Pharmacol. Ther., 15, 97-105 (1999).

3）矢野育子，乾賢一, “月刊眼科診療プラクティス 55 「眼科での内服と注射”，本田孔士編集，文光 堂，東京，2000, pp. 56-57.

4) H.D. Hoskins Jr., M.A. Kass, "BECKER-SHAFFER' $S$ Diagnosis and Therapy of the Glaucomas". 6 th ed. The C.V. Mosby Company, St Louis, 1989, pp. 470-484.

5) D.L. Epstein, W.M. Grant, Carbonic anhydrase inhibitor side effects, Arch. Ophthalmol., 95, 13781382(1977).

6) B.R. Friedland, J. Mallonee, D.R. Anderson, Shortterm dose response characteristics of acetazolamide in man, Arch. Ophthalmol., 95, 1809-1812(1977).

7) B. Lehmann, E. Linnér, P.J. Wistrand, "Schering workshop in pharmacokinetics, Advances in the Biosciences 5 ”, G. Rospe (ed), Pergamon Press Inc., New York, 1969, pp. 197-217.

8) A. Alm, L. Berggren, P. Hartvig, M. Roosdorp, Monitoring acetazolamide treatment, Acta Ophthalmol. (Copenh.), 60, 24-34(1982).

9) F.G. Berson, D.L. Epstein, W.M. Grant, B.T. Hutchinson, P.C. Dobbs, Acetazolamide dosage forms in the treatment of glaucoma, Arch. Ophthalmol., 98, 1051-1054 (1980).

10) P.J. Wistrand, The use of carbonic anhydrase inhibitors in ophthalmology and clinical medicine, Ann. N. Y. Acad. Sci., 429, 609-619(1984).

11) M.H. Schwenk, W.L. St. Peter, M.G. Meese, P.C. Singhal, Acetazolamide toxicity and pharmacokinetics in patients receiving hemodialysis, Pharmacotherapy, 15, 522-527(1995).

12) D.J. Chapron, K.R. Sweeney, P.U. Feig, P.A. Kramer, Influence of advanced age on the disposition of acetazolamide, Br. J. Clin. Pharmacol., 19, 363371 (1985).

13) D.J. Chapron, I.H. Gomolin, K.R. Sweeney, Acetazolamide blood concentrations are excessive in the elderly : Propensity for acidosis and relationship to renal function, J. Clin. Pharmacol., 29, 348-353 (1989).

14) D.W. Cockcroft, M.H. Gault, Prediction of creatinine clearance from serum creatinine, Nephron, 16, 3141(1976).

15) D.M. Chambers, M.H. White, H.B. Kostenbauder, Efficient extraction and reversed-phase high-performance liquid chromatography-ultraviolet quantitation of acetazolamide in serum, J. Chromatogr., 225, 231-235(1981).

16) L.B. Sheiner, B. Rosenberg, V.V. Marathe, Estimation of population characteristics of pharmacokinetic parameters from routine clinical data, J. Pharmacokinet. Biopharm., 5, 445-479(1977).

17) S.L. Beal, A.J. Boeckmann, L.B. Sheiner, NONMEM Users Guides, NONMEM Project Group, University of California, San Francisco, 1992.

18) I. Heller, J. Halevy, S. Cohen, E. Theodor, Significant metabolic acidosis induced by acetazolemide, Arch. Intern. Med., 145, 1815-1817(1985).

19) M. Inui, H. Azuma, T. Nishimura, N. Hatada, “Advances in Epileptology”, H. Akimoto, H. Kazamatsuri, M. Seino, A.A. Ward, Jr. (eds.), Raven Press, New York, 1982, pp. 307-309.

20) P.J. Wistrand, P. Baathe, Inhibition of carbonic anhydrase activity of whole erythrocytes, Acta Pharmacol. et Toxicol., 26, 145-168(1968).

21）“腎機能別薬剤使用マニュアル”, 乾賢一, 土井 俊夫編著，薬業時報社，東京，1999. 